\title{
POJAM PRAVA I (DRUŠTVENA) UČINKOVITOST - ANALITIČKI PRISTUP -
}

Sažetak:

\begin{abstract}
Jedno od značenja izraza 'učinkovitost' odnosi se na činjenicu da se adresati pravnih normi stvarno ponašaju onako kako to od njih zahtijevaju pravne norme. To se značenje izraza obično koristi u filozofskopravnim raspravama glede toga je li učinkovitost bitan element pojma prava. Prema pravnom pozitivizmu, učinkovitost je u nekim slučajevima i na određene načine uvjet važenja (vrijeđenja) pravnih normi i pravnih sustava. S druge strane, pravni je realizam sklon potpunom poistovjećivanju pravnog važenja s učinkovitosti ili njegovu svođenju na učinkovitost. Prema tome, u oba je filozofskopravna pravca učinkovitost u pravilu uključena u oblikovanje njihovih pojmova prava. Međutim, dok pravnopozitivističko shvaćanje ne utječe na najuobičajenije značenje važenja pravne norme (pripadanje pravne norme pravnom sustavu), a utvrđivanjem učinkovitosti kao kriterija postojanja pravnog sustava ne dodaje mnogo objašnjenju pojma prava, pravnorealističko se shvaćanje suočava s ozbiljnim prigovorima glede svoje objašnjavalačke prikladnosti.
\end{abstract}

Ključne riječi: pojam prava, pravno važenje (vrijeđenje), (društvena) učinkovitost, pravna norma, pravni sustav

\section{UVOD}

Neke filozofskopravne teorije (društvenu) učinkovitost (ili, kako je se još naziva, efektivnost ili efikasnost) smatraju jednim od bitnih elemenata svojih pojmova prava. To je očito u onim pravnopozitivističkim teorijama koje učinkovitost do određene mjere smatraju uvjetom pravnog važenja (vrijeđenja), a još više u onim realističkim teorijama koje imaju sklonost pravno važenje identificirati s učinkovitošću ili ga svesti na učinkovitost. Prirodnopravne teorije, naravno, ne pridaju veliku pozornost pojmu učinkovitosti jer važenje pravne norme smatraju neovisnim o njezinoj učinkovitosti. ${ }^{1}$

* Dr. sc. Luka Burazin, docent na Katedri za opću teoriju prava i države Pravnog fakulteta Sveučilišta u Zagrebu. Trg Republike Hrvatske 14, 10000 Zagreb. Adresa e-pošte: lburazin@pravo.hr. ORCID: http://orcid.org/0000-0002-2437-8871.

1 Bulygin, E., The Concept of Efficacy, u: Bulygin, E., Essays in Legal Philosophy, Bernal, C.; Huerta, C.; Mazzarese, T.; Moreso, J. J.; Navarro, P.E.; Paulson, S.L. (ur.), Oxford University Press, New York, 2015, str. 37.; Kelsen, H., Pure Theory of Law, University of 
Izraz učinkovitost ima različita značenja u okviru pravnog diskursa. On se primjerice može odnositi na sposobnost pravnih normi da proizvode pravne učinke (dodjeljivanje prava, nametanje obveza i odgovornosti) ${ }^{2}$ ili na njihovu sposobnost da ostvaraju ciljeve zbog kojih su proizvedene ili na činjenicu da se njihovi adresati stvarno ponašanju onako kako to od njih zahtijevaju norme. ${ }^{3}$ Potonji je smisao onaj koji se redovito uporabljuje u okviru filozofskopravnih rasprava o tome je li učinkovitost bitan element pojma prava i koji ću podrobnije analizirati u sljedećem poglavlju.

Činjeničnim pitanjima glede učinkovitosti pojedinih pravnih normi ili pravnih sustava ili preciznije, pitanjem utvrđivanja, na temelju empirijskog istraživanja, je li neka norma ili pravni sustav (ne)učinkovit i u kojoj mjeri bavi se sociologija prava. ${ }^{4}$ Nasuprot tome, ono što zanima filozofe prava jest 'učinkovitost' kao analitičko pitanje. Zadaća je filozofije prava da utvrdi uvjete pod kojima se neku normu ili pravni sustav može okarakterizirati kao učinkovi$\mathrm{t}(\mathrm{u})$ ili neučinkovit(u) ili uvjete pod kojima su tvrdnje o učinkovitosti (npr. 'Norma $N$ je učinkovita' ili 'Pravni sustav PS je učinkovit') istinite. ${ }^{5}$

\section{POJAM UČINKOVITOSTI}

Učinkovitost može biti predikat pravnih normi i pravnih sustava. ${ }^{6}$ Kao predikat (proglašenih ili postavljenih) pravnih normi, učinkovitost označava svojstvo ili kvalitetu pravne norme. ${ }^{7}$ Kaže se da su pravne norme učinkovite ako se njihovi adresati stvarno ponašaju onako kako je propisano normama. Međutim, shvaćanja se razlikuju glede toga koje adresate treba uzeti u obzir. Neki tvrde da je važno samo ili ponajprije ponašanje građana (tj. da je norma učinkovita ako i samo ako se građani ponašaju u skladu s njom ili je poštuju). ${ }^{8}$ Drugi tvrde da je jedini kriterij za ocjenjivanje učinkovitosti pravnih normi njihova primjena ili potencijalna primjena od organa primjene prava (tj. da je norma učinkovita ako i samo ako je sudovi primjenjuju ili ako postoji razlog da se pretpostavi da će norma biti primijenjena u svakoj budućoj

California Press, Berkeley, Los Angeles, 1967 [1960], str. 211.; Ross, A., On Law and Justice, Stevens \& Sons Limited, London, 1958, str. 18.

2 U hrvatskom prijevodu Guastinijeve Sintakse prava za to se značenje učinkovitosti koristi sintagma 'sposobnost (pravnog) djelovanja' ili '(pravna) djelovnost'. Vidi Guastini, R., Sintaksa prava, Naklada Breza, Zagreb, 2016, str. 237. i 291.-292.

3 Pino, G., Norma giuridica, u: Pino, G.; Schiavello, A.; Villa, V. (ur.), Filosofia del diritto. Introduzione critica al pensiero giuridico e al diritto positivo, G. Giappichelli Editore, Torino, 2013, str. 174.-177.; Hernández Marín, R., Introducción a la teoría de la norma jurídica, Marcial Pons, Madrid, Barcelona, 2002, str. 279.-284.

4 Bryde, B.-O., Die Effektivität von Recht als Rechtsproblem, De Gruyter, Berlin, New York, 1993, str. 7.-12.; Bobbio, N., Teoria generale del diritto, G. Giappichelli Editore, Torino, 1993, str. 25.; Navarro, P.E., La Eficacia del Derecho. Una investigación sobre la Existencia y Funcionamiento de los Sistemas Jurídicos, Centro de Estudios Constitutionales, Madrid, 1990, str. 20.; Alexy, R., The Argument from Injustice. A Reply to Legal Positivism, Oxford University Press, New York, 2002, str. 86.

5 Bulygin, op. cit. u bilj. 1, str. 37.; Navarro, op. cit. u bilj. 4, str. 20.

6 Greppi, A., Eficacia, Eunomía, 3, 2012, str. 152.

7 Drukčije Kelsen, koji učinkovitost smatra kvalitetom ljudskog ponašanja. Vidi Kelsen, H., General Theory of Law and State, Harvard University Press, Cambridge, Massachusetts, 1945, str. 40.

8 Grabowski, A., Juristic Concept of the Validity of Statutory Law. A Critique of Contemporary Legal Nonpositivism, Springer, Berlin, Heidelberg, 2013, str. 341.-342.; Navarro, P. E., Moreso, J. J., Applicability and Effectiveness of Legal Norms, Law and Philosophy, 16, 1997, str. 201. 
sudskoj odluci). ${ }^{9}$ Treći pak tvrde da se učinkovitost pravnih normi sastoji ponajprije u njihovoj primjeni od organa primjene prava, a podredno i u tome da ih poštuju građani. ${ }^{10}$ Konačno, neki tvrde, a to se čini i prevladavajućim shvaćanjem, da je norma učinkovita i ako se građani ponašaju u skladu s njom ili je poštuju i, u slučaju kada tako ne učine, ako je primijene organi primjene prava. ${ }^{11}$ Te se dvije razine učinkovitosti - ona koja se odnosi na poštovanje normi od građana i ona koja se odnosi na primjenu normi od organa primjene prava - katkad nazivaju 'primarnom' i 'sekundarnom' učinkovitošću pravnih normi. ${ }^{12}$

Značenje tvrdnji o učinkovitosti tako ovisi o smislu koji se pripiše pojmu ponašanja u skladu s normom ili poštovanja norme, s jedne strane, i pojmu primjene norme, s druge. Pojam ponašanja u skladu s normom može se shvatiti na barem dva različita načina. Može se reći da se ponašanje u skladu s normom sastoji već u samoj činjenici da se stvarno ponašanje adresata podudara s onim što je zahtijevano normom, tj. da je stvarno ponašanje adresata suglasno pravnim normama ${ }^{13}$ ili da postoji jednostavan "odraz ponašanja u normi”. ${ }^{14}$ Prema nekima, pravo od svojih subjekata kao dovoljno traži upravo takvo normama sukladno ponašanje. ${ }^{15}$ Dakle, kaže se da je norma $N$ učinkovita ako se činjenično stanje (stvarno ponašanje adresata normi) podudara s normativnim sadržajem $N$-a ili ako postoji odnos identiteta između "zahtijevanog" i "proizvedenog" ponašanja. ${ }^{16}$ Takvo ponašanje sukladno normama čini učinkovitost odnosom podudaranja ili suglasja ${ }^{17}$ pa se takva učinkovitost naziva tzv. ciljnom učinkovitošću. ${ }^{18} \mathrm{~S}$ druge strane, pojam ponašanja u skladu s normom može se shvatiti i u smislu da se adresati pokoravaju pravnim normama, tj. u smislu da adresati slijede norme, ponašaju se onako kako norme propisuju upravo zbog toga što norme propisuju takvo ponašanje. ${ }^{19} \mathrm{Ta}-$ kvo se ponašanje u skladu s normom može definirati kao svjesno ponašanje u skladu s pravnom normom, ${ }^{20}$ pri čemu je postojanje pravne norme "odlučujući čimbenik za normi suglasno ponašanje”. ${ }^{21}$ Stoga se može reći da je norma $N$ učinkovita ako se činjenično stanje (stvarno

Ross, op. cit. u bilj. 1, str. 35.-36., 40.-41.; Ingram, P., Effectiveness, ARSP, 69(4), 1983, str. 496.-497.

Kelsen, H., Reine Rechtslehre, zweite, vollständig neu bearbeitete und erweiterte Auflage, Wien, 1960, str. 11.; Kelsen, H., General Theory of Norms, Oxford University Press, New York, 1991 [1979], str. 3.; Kelsen, H., Validity and Efficacy of the Law, u: Bulygin, E., Essays in Legal Philosophy, Bernal, C.; Huerta, C.; Mazzarese, T.; Moreso, J. J.; Navarro, P. E.; Paulson, S.L. (ur.), Oxford University Press, 2015 [1967], str. 60.-63.; Bobbio, op. cit. u bilj. 4, str. 25; Alexy, op. cit. u bilj. 4, str. 85.; Pino, op. cit. u bilj. 3, str. 174.-175.; Perić, B., Struktura prava, Informator, Zagreb, 1994., str. 31.; Visković, N., Pojam prava. Prilog integralnoj teoriji prava, Pravni fakultet u Splitu, Split, 1976., str. 236.-237.

12 Ferrajoli, L., Principia iuris. Teoria del diritto e della democrazia. Vol. 1. Teoria del diritto, Laterza, Roma-Bari, 2007, str. 451.-452. Perić, op. cit. u bilj. 11, str. 31.; Visković, op. cit. u bilj. 11, str. 236.-237.; Vrban, D., Država i pravo, Golden marketing, Zagreb, 2003., str. 480.

13 Kelsen, op. cit. u bilj. 7, str. 41.; Kelsen, op. cit. u bilj. 1, str. 15.; Hernández Marín, op. cit. u bilj. 3, str. $284 .-287$.

14 Shiner, R., Norm and Nature, Oxford University Press, New York, 1992, str. 24.

15 Hernández Marín, op. cit. u bilj. 3, str. 288.-289.

16 Navarro, op. cit. u bilj. 4, str. 59.

17 Kelsen, H., Reine Rechtslehre. Einleitung in die rechtswissenschaftliche Problematik, Franz Deuticke, Leipzig, Wien, 1934, str. 31.32, Kelsen, op. cit. u bilj. 7, str. 39.-40.; Kelsen, op. cit. u bilj. 1, str. 10.-11.; Pino, op. cit. u bilj. 3, str. 174.

18 Grabowski, op. cit. u bilj. 8, str. 335.

19 Hoerster, N., Was ist Recht? Grundfragen der Rechtsphilosophie, C. H. Beck, München, 2006, str. 48.-50.; Perić, op. cit. u bilj. 11, str. 31.-32.

20 Hernández Marín, op. cit. u bilj. 3, str. 287.-288. 
ponašanje adresata norme) podudara s normativnim sadržajem $N$-a i adresati norme svjesno proizvode zahtijevano ponašanje na temelju $N$-a. Taj oblik ponašanja u skladu s normom čini učinkovitost odnosom pokoravanja pa se takvu učinkovitost naziva i tzv. motivacijskom ili psihološkom učinkovitošću. ${ }^{22}$

Određeni su prigovori izneseni u odnosu na obje ove interpretacije učinkovitosti. Primjerice, prigovara se da tzv. ciljna učinkovitost može ovisiti o pukom slučajnom podudaranju ponašanja adresata s normom, da je to pojam koji se može primijeniti iz potpuno vanjskog gledišta, da to nije dokaz da norma ima propisujuću snagu, da ona ne uzima u obzir važnu ideju slijeđenja pravila, ${ }^{23}$ da ne uspijeva opisati način na koji se nositelji pravne vlasti ponašaju suglasno pravu $^{24}$ ili da postaje problematična ako je se koristi kao kriterij za određivanje ili utvrđivanje pravnih normi i pravnih sustava. ${ }^{25} \mathrm{~S}$ druge strane, tzv. motivacijska ili psihološka učinkovitost kritizira se na sljedećim osnovama: kaže se da je u većini slučajeva nemoguće utvrditi stvarne motive za ponašanje sukladno normi ${ }^{26}$ pa onda i stupanj učinkovitosti shvaćene u psihološkom smislu. ${ }^{27}$

Kao i ponašanje u skladu s normom i primjena norme može se shvatiti na različite načine. Prema jednom gledištu, tvrdi se da se primjena norme koja je čini učinkovitom sastoji u određivanju i izvršenju sankcija od organa primjene prava u slučajevima gdje se pravni subjekti ne ponašaju u skladu s pravom. ${ }^{28}$ Dakle, može se reći da je norma $N$ učinkovita ako organi primjene prava određuju i izvršavaju sankcije za 'kršenje' prava. Prema drugom gledištu, primjena norme sastoji se u njezinoj uporabi u svojstvu premise u sudskom rasuđivanju, tj. kao "sastavni dio rasuđivanja na kojemu se temelji presuda" i "jedan od odlučujućih čimbenika koji određuju zaključak do kojega je došao sud", ${ }^{29}$ "posve neovisno o tome završava li postupak oslobađanjem ili osudom optuženika". ${ }^{30}$ Dakle, može se reći da ja norma $N$ učinkovita ako je organi primjene prava (tj. sudovi) uporabljuju za utemeljivanje svojih odluka. Konačno, pojam primjene norme može se proširiti i na upotrebu dopuštenja i ovlasti (pravnih vlasti) od adresata normi (i građana i nositelja pravne vlasti). ${ }^{31}$ Dakle, može se reći da je dopuštajuća ili ovlašćujuća norma $N$ učinkovita ako njezini adresati uporabljuju dopuštenje ili vlast koju im dodjeljuje $N$. Razlika u odnosu na zapovjedne i zabranjujuće norme (tj. norme kojima se nameću dužnosti) jest u tome što su potonje neučinkovite kada se adresati ne ponašaju u skladu s njima, dok se dopuštajuće i ovlašćujuće norme "ne mogu okarakterizirati kao neučinkovite u slučaju kada se ne uporabljuje ovlast ili dopuštenje". ${ }^{32}$ Ovdje, međutim, treba napomenuti

\footnotetext{
22 Grabowski, op. cit. u bilj. 8, str. 335. 
da je, prema nekim autorima, "učinkovitost u bitnome značajka D-pravila [pravila kojima se nameću dužnosti], dok se ona u slučaju P-pravila [pravila kojima se dodjeljuju prava] potvrđuje prvenstveno na temelju njihova odnosa s učinkovitim D-pravilima". ${ }^{33}$

Interpretacija učinkovitosti u smislu primjene norme od organa primjene prava također je naišla na određene prigovore. Tvrdi se primjerice da je izraz "primjenjuje” višeznačan jer se sud koji ga uključuje može odnositi na prošle, sadašnje ili buduće primjene norme. ${ }^{34}$ Prema Bulyginu, sud 'Norma $N$ je učinkovita, tj. sudci primjenjuju $N$ ' "očito se ne može odnositi na prošlost, jer je moguće da je norma koja je ranije bila primjenjivana u međuvremenu izgubila svoju učinkovitost, i očito ne može biti isključivo stvar sadašnje primjene, jer bi to pretjerano ograničilo doseg primjene riječi 'učinkovit", a ne može se odnositi ni na buduću primjenu, jer se "u toj interpretaciji, značenje riječi 'učinkovit' jako udaljava od njezine uobičajene upotrebe u pravnom diskursu”. ${ }^{35}$

Dok se sve gorenavedene interpretacije učinkovitosti (i u smislu ponašanja u skladu s normom i u smislu primjene norme) odnose na "činjeničnu dimenziju norme", tj. na stvarno ponašanje adresata normi pa se stoga suočavaju s ozbiljnim teškoćama, Bulygin je predložio interpretaciju učinkovitosti u smislu osobite dispozicije norme, tj. dispozicije norme da bude primijenjena kada su ispunjeni određeni uvjeti. ${ }^{36}$ Prema toj interpretaciji, "sud "norma $N$ je učinkovita' istovrijedan je sudu 'ako bi određeni uvjeti bili ispunjeni (oni nužni za primjenu), onda bi sudovi primjenjivali $N$ ". ${ }^{37}$ Dakle, može se reći da je norma $N$ učinkovita ako i samo ako se sud na nju može pozvati. ${ }^{38}$ Prema tom gledištu, učinkovitost se ne odnosi na činjenicu ponašanja u skladu s normom ili činjenicu primjene norme, nego na posebnu dispoziciju norme, tj. na njezinu sudsku pozivljivost (judicial invokability). ${ }^{39}$

Koju god interpretaciju učinkovitosti u smislu stvarnog ponašanja adresata (isključujući dakle Bulyginovu interpretaciju) smatrali najprihvatljivijom, prevladavajuće je shvaćanje da je učinkovitost pravne norme stvar stupnja. ${ }^{40}$ Norma može biti više ili manje učinkovita. Ako se za normu kaže da je učinkovita, to "ne znači da je se uvijek i beziznimno poštuje i primjenjuje; to znači samo da je se uglavnom poštuje i primjenjuje". ${ }^{41}$ Štoviše, kaže se da "uvijek mora postojati mogućnost da ona neće biti poštovana ili primijenjena, jer ako ta mogućnost ne bi postojala ( $\mathrm{tj}$. ako se to što se treba dogoditi mora dogoditi uvijek i beziznimno, na temelju prirodnih zakona), onda bi norma koja određuje to ponašanje kao obvezno bila suvišna. Kao što je besmisleno postaviti normu koja obveznim određuje nešto za što se unaprijed zna da se na temelju prirodnih zakona nikada ne može dogoditi" ${ }^{42}$

Munzer, S., Legal Validity, Martinus Nijhoff, The Hague, 1972, str. 34.

Bulygin, op. cit. u bilj. 1, str. 47.

Ibid.

Ibid., str. 48.

Ibid.

Ibid., str. 50.

Za prigovore glede ove interpretacije učinkovitosti vidi Kelsen, Validity.., op. cit. u bilj. 11, str. 66.-67., bilj. 14.

Kelsen, General..., op. cit. u bilj. 11, str. 138.-139.; Pino, op. cit. u bilj. 3, str. 175.; Grabowski, op. cit. u bilj. 8, str. 335.; Navarro, op. cit. u bilj. 4, str. 22.; Alexy, op. cit. u bilj. 4, str. 85.

Kelsen, General..., op. cit. u bilj. 11, str. 138.

Ibid., str. 138.-139. 
U vezi s učinkovitosti kao predikata pravnih sustava, prevladavajuće je stajalište u filozofiji prava da je pravni sustav $P S$ učinkovit ako i samo ako je većina njegovih normi učinkovita. ${ }^{43} \mathrm{Iz}$ toga slijedi da je i učinkovitost pravnog sustava stvar stupnja ${ }^{44}$ i da ovisi o tome koju od navedenih interpretacija učinkovitosti prihvatimo. Međutim, s obzirom na prevladavajuće stajalište da je norma učinkovita i kada se građani ponašaju s njom u skladu ili je poštuju i, ako tako ne učine, kada je primjenjuju organi primjene prava, navedeni je uvjet učinkovitosti pravnog sustava (naime, da je većina $P S$-ovih normi učinkovita) otvorio niz važnih pitanja. Primjerice: je li uopće moguće napraviti jednostavan izračun svih pravnih normi pravnog sustava, a zatim odrediti razmjere učinkovitosti sustava; jesu li sve povrede svih normi jednako važne; jesu li sve povrede iste norme jednako važne; postoji li razlika u procjenjivanju učinkovitosti normi kojima se nameću dužnosti i normi kojima se dodjeljuju prava; bi li veću važnost trebalo pridati važnim ustavnim normama; treba li u obzir uzeti samo suglasnost ponašanja normi ili također neko znanje o pravu i kako ono motivira ponašanje adresata normi; imaju li nepravni čimbenici kakvu ulogu u utvrđivanju učinkovitosti; treba li kao objektivniji način utvrđivanja učinkovitosti u obzir uzeti samo primjenu normi od organa primjene prava. ${ }^{45}$ Nadalje, čak i ako se primjenu prava uzme kao jedini kriterij učinkovitosti i dalje postoji problem utvrđivanja omjera stvarne i zahtijevane primjene koji je nužan za utvrđivanje učinkovitosti ili neučinkovitosti te problem utvrđivanja područja primjene prava koja su značajnija za učinkovitost pravnog sustava kao cjeline. ${ }^{46}$

\section{UČINKOVITOST KAO UVJET PRAVNOG VAŽENJA}

U okviru pravnog pozitivizma rašireno je shvaćanje da je učinkovitost u nekim slučajevima i na određene načine uvjet pravnog važenja. Naravno, treba uzeti u obzir činjenicu da je izraz 'važenje' izrazito višeznačan ${ }^{47}$ i da se njegova različita značenja različito odnose na pitanje veza između učinkovitosti i važenja. ${ }^{48}$

Ovdje možemo navesti barem tri zanimljiva pitanja. Prvo, postoji li veza između učinkovitosti pravne norme i njezinog važenja? Drugo, postoji li veza između učinkovitosti pravnog sustava i važenja pravne norme? Treće, postoji li veza između učinkovitosti pravnog sustava i njegova važenja?

U vezi s prvim pitanjem, prevladavajuće je stajalište da učinkovitost (proglašene ili postavljene) pravne norme nije (ni nužni ni dovoljni) uvjet njezina važenja shvaćenog u smislu pripadanja norme pravnom sustavu. ${ }^{49}$ Općenito je prihvaćeno da tzv. izvedene pravne norme

43 Navarro, op. cit. u bilj. 4, str. 71.; Munzer, op. cit. u bilj. 33, str. 32.

Kelsen, op. cit. u bilj. 17, str. 68.-69.; Navarro, op. cit. u bilj. 4, str. 71.-72.

46 Ingram, op. cit. u bilj. 9, str. 501.

47 Nino, C. S., Introduzione all'analisi del diritto, G. Giappichelli Editore, Torino, 1996, str. 116.-118.

48 Bulygin, E., Il positivismo giuridico, Giuffrè editore, Milano, 2007, str. 110.-111.

49 Kelsen, op. cit. u bilj. 1, str. 11.; Munzer, op. cit. u bilj. 33, str. 43.; Shiner, op. cit. u bilj. 14, str. 28.; Bobbio, op. cit. u bilj. 4, str. 27. Hart, H. L. A., The Concept of Law, Oxford University Press, New York, 1994, str. 103.; Hoerster, op. cit. u bilj. 19, str. 51.; Bulygin, 
(tj. one čije je postojanje utemeljeno na postojanju drugih pravnih normi) pripadaju pravnom sustavu (te su u tom smislu pravno važeće ili vrijedeće) na temelju normi koje uređuju njihovo stvaranje i pod pretpostavkom da su barem prima facie stvorene u skladu s tim normama (ono što je nužno jest barem da su stvorene od nadležnog tijela vlasti). ${ }^{50}$ Tako se primjerice tek doneseni zakon, iako ga se još ne poštuje ili ne primjenjuje, ipak smatra važećom pravnom normom ako ga je donio parlament. Zapravo, neki tvrde da je stvar upravo obrnuta, tj. ne da je učinkovitost uvjet važenja, nego da je važenje pravne norme (u smislu pripadanja norme pravnom sustavu) nužni uvjet njezine učinkovitosti. ${ }^{51}$ Naravno, to se ne odnosi na običajne norme "jer se njihovo postojanje, a onda i njihovo pripadanje sustavu, sastoji u njihovoj učinkovitosti". ${ }^{2} \mathrm{~S}$ druge strane, tvrdi se da je učinkovitost pravne norme uvjet njezina važenja u smislu da norma gubi svoje važenje ako postane trajno neučinkovita. ${ }^{53}$ To se, kaže se, događa u slučaju desuetudo (tj. kada norma nije bila poštovana ili primjenjivana tijekom vrlo dugog vremenskog razdoblja). ${ }^{54}$ Međutim, prevladavajuće je shvaćanje da je takav način gubitka važenja samo kontingentan jer ovisi o tome uključuje li konkretan pravni sustav učinkovitost među svoje kriterije važenja. ${ }^{55}$ Također, barem kada je riječ o Kelsenovu shvaćanju, tvrdi se da učinkovitost u ovom slučaju treba protumačiti kao uvjet važenja u smislu 'obvezujuće snage' norme (što za Kelsena znači da se ljudi trebaju ponašati onako kako norma zahtijeva). ${ }^{56} \mathrm{Na}$ taj se način može protumačiti i Kelsenova tvrdnja da norma, "da postane važeća, mora imati mogućnost biti učinkovita, jer norma koja kao obvezno određuje nešto nemoguće [...] ne može biti važeća, s obzirom na to da od početka ne može biti učinkovita" ${ }^{57}$

U vezi s drugim pitanjem, postoji shvaćanje da je učinkovitost pravnog sustava nužan uvjet pravnog važenja, u smislu obvezujuće snage norme,$^{58}$ svih normi koje pripadaju nekom sustavu. Kaže se da se pravna norma smatra važećom (tj. da je obvezujuća) samo ako (uz to što ju je donijelo ili postavilo nadležno tijelo vlasti) pripada pravnom sustavu koji je uglavnom učinko$v{ }^{59}$ te da prestaje biti važeća ako pravni sustav kojemu norma pripada izgubi svoju učinkovitost kao cjelina. ${ }^{60} \mathrm{Ta}$ je veza između učinkovitosti i važenja, kao što kaže Kelsen, "spoznatljiva [...] samo iz gledišta dinamičke teorije prava koja se bavi problemom razloga važenja i pojmom pravnog poretka". ${ }^{61}$ Naime, norma je važeća ako je stvorena u skladu s normom koja uređuje

op. cit. u bilj. 48, str. 110.; Navarro, P. E., The Efficacy of Constitutional Norms, u: d'Almeida, L. D.; Gardner, J., Green, L. (ur.), Kelsen Revisited. New Essays on the Pure Theory of Law, Hart Publishing, Oxford and Portland, Oregon, 2013, str. 80.-81.

Guastini, R., La sintassi del diritto, G. Giappichelli Editore, Torino, 2014, str. 119.

Hoerster, op. cit. u bilj. 19, str. 51.; Aarnio, A., The Formal Validity, Efficacy, and Acceptability of Legal Norms, u: Aarnio, A., Essays on the Doctrinal Study of Law, Springer, Dordrecht, 2011, str. 128.

Bulygin, op. cit. u bilj. 48, str. 120.

Kelsen, Validity..., op. cit. u bilj. 11, str. 67.

Kelsen, op. cit. u bilj. 17, str. 73.; Kelsen, op. cit. u bilj. 7, str. 119.-120.; Kelsen, op. cit. u bilj. 1, str. 213.; Alexy, op. cit. u bilj. 4, str. 91.

Kelsen, op. cit. u bilj. 7, str. 122.; Hart, op. cit. u bilj. 49, str. 103. i 295.; Munzer, op. cit. u bilj. 33, str. 43.

Bulygin, op. cit. u bilj. 48, str. 110.

Kelsen, General..., op. cit. u bilj. 11, str. 140.

Vidi Bulygin, op. cit. u bilj. 48, str. 110.-111.

Kelsen, op. cit. u bilj. 7, str. 42.; Alexy, op. cit. u bilj. 4, str. 91.

Kelsen, op. cit. u bilj. 7, str. 119.; Kelsen, op. cit. u bilj. 1, str. 212.; Hoerster, op. cit. u bilj. 19, str. 51.

Kelsen, op. cit. u bilj. 7, str. 42. 
njezino stvaranje ili, iz gledišta prve karike lanca autorizacije (ili dinamičnog izvođenja), u skladu s prvim ustavom. Međutim, prvi ustav, na temelju tzv. temeljne norme, važi samo ako su on i pravni sustav kojemu pripada u cjelini uzevši učinkoviti. Na taj način, barem posredno, postoji odnos između učinkovitosti i važenja. ${ }^{62}$ Međutim, navedeno shvaćanje ne prihvaćaju svi, tvrdeći naprotiv da opća učinkovitost pravnog sustava nije kriterij važenja, nego samo kontekst koji se obično pretpostavlja kada se pravilo sustava utvrđuje kao važeće pravno pravilo, tj. kada se iznose unutarnje tvrdnje o važenju. ${ }^{63}$

Konačno, uobičajeno je shvaćanje pravnih pozitivista (ali i nekih nepozitivista) da je učinkovitost normi sustava nužan uvjet važenja pravnog sustava u smislu postojanja pravnog sustava, kao što se uobičajeno smatra i da je istinitost tvrdnje da je pravni sustav neučinkovit dovoljna za istinitost tvrdnje da pravni sustav nije važeći (tj. da ne postoji). ${ }^{64}$ Međutim, čak i ako se teškoće povezane s utvrđivanjem točnog značenja izraza učinkovitost ostave po strane, učinkovitost, shvaćena kao uvjet postojanja pravnog sustava, pomaže praviti razliku samo između "učinkovitog i neučinkovitog prava, a ne između pravnih i nepravnih sustava" 65 pa na taj način ne pridonosi mnogo objašnjenju pojma prava.

\section{SVOĐENJE VAŽENJA NA UČINKOVITOST}

Za neke se teorije prava kaže da osporavaju logičku odvojivost važenja od učinkovitosti ili da pravno važenje poistovjećuju s učinkovitošću ili da ga na nju svode. ${ }^{66}$ Ta se shvaćanja obično pripisuju različitim oblicima pravnog realizma. ${ }^{67}$ Tvrdi se da "ako se na pravo gleda [...] kao da se sastoji samo od onoga što čine suci [...], ako se na pravo gleda kao na psihološku činjenicu, kao na prisiljavanje na određene oblike ponašanja kod običnog građanina i sudca, onda jasno slijedi da kvaliteta prava kao prava leži neposredno u stvarnom djelovanju" ${ }^{68}$

Prema Alfu Rossu, jednom od vodećih predstavnika skandinavskog pravnog realizma, pojam 'važeće pravo' “odnosi se na učinkovitost normi kao društvenu činjenicu”. ${ }^{99}$ Važeće pravo, prema Rossu, znači "apstraktni skup normativnih ideja koji služi kao tumačenjska shema za pojave prava u praksi, što pak znači da se te norme stvarno slijede, i slijede zbog toga što su dijelom iskustva i što ih se osjeća kao društveno obvezujuće”. ${ }^{70}$ Oni koji slijede norme su, prema Rossu, suci, jer je "stvarni sadržaj norme o ponašanju naredba sucu, dok je uputa privatnoj

62 Celano, B., La teoria del diritto di Hans Kelsen. Una introduzione critica, Il Mulino, Bologna, 1999, str. 358.

63 Hart, op. cit. u bilj. 49, str. 295.

64 Navarro, op. cit. u bilj. 4, str. 15. i 71.; Kelsen, op. cit. u bilj. 7, str. 120.; Kelsen, op. cit. u bilj. 1, str. 211.-212.; Alexy, op. cit. u bilj. 4, str. 89.-90.; Ingram, op. cit. u bilj. 9, str. 484.; Shiner, op. cit. u bilj. 14, str. 29.; Hart, op. cit. u bilj. 49, str. 103.-104.

65 Raz, J., The Authority of Law. Essays on Law and Morality, Oxford University Press, New York, 2002 [1979], str. 43.

66 Ingram, op. cit. u bilj. 9, str. 490.; Kelsen, op. cit. u bilj. 1, str. 211.; Bobbio, op. cit. u bilj. 4, str. 31.

67 Kelsen, op. cit. u bilj. 1, str. 211.; Bobbio, op. cit. u bilj. 4, str. 31.; Ingram, op. cit. u bilj. 9, str. 490.; Vrban, op. cit. u bilj. 12, str. 480.

68 Ingram, op. cit. u bilj. 9, str. 490.

69 Ross, op. cit. u bilj. 1, str. 19.-20.

$70 \quad$ Ibid., str. 18. 
osobi iz nje deducirana izvedena i figurativna pravna norma" ${ }^{71}$ Prema tome, pravne pojave za koje pravne norme služe kao tumačenjska shema jesu odluke sudova, pa "tu moramo tražiti učinkovitost koja je važenje prava” ${ }^{72}$ Ono što čini pravno važenje norme je, prema tome, njezina primjena od sudaca. U tom smislu Ross svodi važenje na učinkovitost. Važenje je u cijelosti ovisno o učinkovitosti. Ono što normu čini 'važećom' jest činjenica da je sudovi primjenjuju, tj. da je učinkovita. Ponašanje građana u skladu s pravnom normom nema nikakvu ulogu u utvrđivanju njezine učinkovitosti, što dovodi do paradoksalnog zaključka da je to teže utvrditi posjeduje li norma pravno važenje što se više njezini adresati ponašaju u skladu s njom. ${ }^{73}$ Imajući u vidu svoje shvaćanje prema kojem je važenje potpuno ovisno o učinkovitosti, Ross razmatra slučaj nedavno proglašenog, no i dalje neučinkovitog zakona te zaključuje da taj zakon treba smatrati važećim pod uvjetom da "na nekoj osnovi različitoj od prethodne sudske prakse postoji razlog da se pretpostavi da će pravilo biti primijenjeno u svakoj budućoj sudskoj odluci" ${ }^{74}$

U odnosu na pravni sustav kao cjelinu, Ross na odgovarajući način definira važenje u smislu učinkovitosti normi sustava pa tako i važenje sustava svodi na njegovu učinkovitost. Međutim, budući da se, prema Rossu, pravni sustav sastoji samo od "normi koje su stvarno operativne u svijesti sudca, jer ih on osjeća kao društveno obvezujuće i stoga im se pokorava”, ${ }^{75}$ u Rossovoj teoriji, za razliku od pravnopozitivističkih teorija prava, učinkovitost ne može biti stvar stupnja: "ukupnost prava se nalazi u zbroju učinkovitosti svih pojedinih normi". ${ }^{76}$

Neki od prigovora koji su upućeni takvom objašnjenju važenja jesu da je "nemoguće shvatiti specifično značenje u kojem se pravo obraća stvarnosti i time suprotstavlja stvarnosti, koja može biti u suglasju ili sukobu s pravom samo ako stvarnost nije istovjetna važenju prava"; 77 da to objašnjenje ne može objasniti pojave kao što su desuetudo, tzv. simbolično pravo (tj. norme donesene bez prave namjere da budu provedene) i idealni slučaj pravnog važenja (tj. kada se svi građani u svim slučajevima ponašaju u skladu s normom pa suci nemaju priliku da je primijene); da ono vodi k (protuintuitivnoj) stupnjevitosti pojma pravnog važenja (budući da bi se za normu onda moglo reći da je manje ili više važeća ovisno o stupnju njezine primjene ili vjerojatnosti s kojom se može predvidjeti da će biti primijenjena); te da ne može objasniti činjenicu da suci katkad primjenjuju pravo za koje se poslije ispostavi da je nevažeće (npr. u slučajevima unatražnodjelujućeg poništenja zakona). ${ }^{78}$

\footnotetext{
71 Ibid., str. 33.

72 Ibid., str. 34.-35.

73 Ibid., str. 35.-36.

74 Ibid., str. 40.-41.

75 Ibid., str. 35.

76 Ingram, op. cit. u bilj. 9, str. 490.

77 Kelsen, op. cit. u bilj. 1, str. 213.

78 Grabowski, op. cit. u bilj. 8, str. 316.-319.
} 


\section{ZAKLJUČAK}

Jedno od značenja izraza 'učinkovitost' odnosi se na činjenicu da se adresati pravnih normi stvarno ponašaju onako kako to od njih zahtijevaju pravne norme. To se značenje izraza obično koristi u filozofskopravnim raspravama glede toga je li učinkovitost bitan element pojma prava. Prema pravnom pozitivizmu, učinkovitost je u nekim slučajevima i na određene načine uvjet važenja pravnih normi i pravnih sustava. S druge strane, pravni je realizam sklon potpunom poistovjećivanju pravnog važenja s učinkovitosti ili njegovom svođenju na učinkovitost. Prema tome, u oba je filozofskopravna pravca učinkovitost u pravilu uključena u oblikovanje njihovih pojmova prava. Međutim, dok pravnopozitivističko shvaćanje ne utječe na najuobičajenije značenje važenja pravne norme (pripadanje pravne norme pravnom sustavu), a utvrđivanjem učinkovitosti kao kriterija postojanja pravnog sustava ne dodaje mnogo objašnjenju pojma prava, pravnorealističko se shvaćanje suočava s ozbiljnim prigovorima glede svoje objašnjavalačke prikladnosti.

\section{LITERATURA}

1. Aarnio, A., The Formal Validity, Efficacy, and Acceptability of Legal Norms, u: Aarnio, A., Essays on the Doctrinal Study of Law, Springer, Dordrecht, 2011, str. 125.-130.

2. Alexy, R., The Argument from Injustice. A Reply to Legal Positivism, Oxford University Press, New York, 2002.

3. Bobbio, N., Teoria generale del diritto, G. Giappichelli Editore, Torino, 1993.

4. Bryde, B.-O., Die Effektivität von Recht als Rechtsproblem, De Gruyter, Berlin, New York, 1993.

5. Bulygin, E., Il positivismo giuridico, Giuffrè editore, Milano, 2007.

6. Bulygin, E., The Concept of Efficacy, u: Bulygin, E., Essays in Legal Philosophy. Bernal, C., Huerta, C., Mazzarese, T., Moreso, J. J., Navarro, P. E., Paulson, S. L. (ur.), Oxford University Press, 2015, str. 37.-51.

7. Celano, B., La teoria del diritto di Hans Kelsen. Una introduzione critica, Il Mulino, Bologna, 1999.

8. Ferrajoli, L., Principia iuris. Teoria del diritto e della democrazia. Vol. 1. Teoria del diritto, Laterza, Roma-Bari, 2007.

9. Grabowski, A., Juristic Concept of the Validity of Statutory Law. A Critique of Contemporary Legal Nonpositivism, Springer, Berlin, Heidelberg, 2013.

10. Greppi, A., Eficacia, Eunomía, 3, 2012, str. 150.-159.

11. Guastini, R., La sintassi del diritto, G. Giappichelli Editore, Torino, 2014.

12. Guastini, R., Sintaksa prava, Naklada Breza, Zagreb, 2016.

13. Hart, H. L. A., The Concept of Law, Oxford University Press, New York, 1994.

14. Hernández Marín, R., Introducción a la teoría de la norma jurídica, Marcial Pons, Madrid, Barcelona, 2002.

15. Hoerster, N., Was ist Recht? Grundfragen der Rechtsphilosophie, C. H. Beck, München, 2006.

16. Ingram, P., Effectiveness, ARSP, 1983, 69(4), str. 484.-503.

17. Kelsen, H., Reine Rechtslehre. Einleitung in die rechtswissenschaftliche Problematik, Franz Deuticke, Leipzig, Wien, 1934. 
18. Kelsen, H., General Theory of Law and State, Harvard University Press, Cambridge, Massachusetts, 1945.

19. Kelsen, H., Reine Rechtslehre, zweite, vollständig neu bearbeitete und erweiterte Auflage. Wien, 1960.

20. Kelsen, H., Pure Theory of Law, University of California Press, Berkeley, Los Angeles, 1967 [1960].

21. Kelsen, H., General Theory of Norms, Oxford University Press, New York, 1991 [1979].

22. Kelsen, H., Validity and Efficacy of the Law, u: Bulygin, E., Essays in Legal Philosophy, Bernal, C., Huerta, C., Mazzarese, T., Moreso, J. J., Navarro, P. E., Paulson, S. L. (ur.), Oxford University Press, 2015 [1967], str. 52.-68.

23. Lagerspetz, E., The Opposite Mirrors. An Essay on the Conventionalist Theory of Institutions, Kluwer Academic Publishers, Dordrecht, 1995.

24. Munzer, S., Legal Validity, Martinus Nijhoff, The Hague, 1972.

25. Navarro, P. E., La Eficacia del Derecho. Una investigación sobre la Existencia y Funcionamiento de los Sistemas Jurídicos, Centro de Estudios Constitutionales, Madrid, 1990.

26. Navarro, P. E., The Efficacy of Constitutional Norms, u: d'Almeida, L. D., Gardner, J., Green, L. (ur.), Kelsen Revisited. New Essays on the Pure Theory of Law, Hart Publishing, Oxford and Portland, Oregon, 2013, str. 77.-99.

27. Navarro, P. E., Moreso, J. J., Applicability and Effectiveness of Legal Norms, Law and Philosophy, 1997, 16, str. 201.-219.

28. Nino, C. S., Introduzione all'analisi del diritto, G. Giappichelli Editore, Torino, 1996.

29. Perić, B., Struktura prava, Informator, Zagreb, 1994.

30. Pino, G., Norma giuridica, u: Pino, G., Schiavello, A.; Villa, V. (ur.), Filosofia del diritto. Introduzione critica al pensiero giuridico e al diritto positivo, G. Giappichelli Editore, Torino, 2013, str. 144.-183.

31. Raz, J., The Authority of Law. Essays on Law and Morality, Oxford University Press, New York, 2002 [1979].

32. Raz, J., The Concept of a Legal System. An Introduction to the Theory of Legal System, Oxford University Press, New York, 2003 [1980].

33. Ross, A., On Law and Justice, Stevens \& Sons Limited, London, 1958.

34. Shiner, R., Norm and Nature, Oxford University Press, New York, 1992.

35. Visković, N., Pojam prava. Prilog integralnoj teoriji prava, Pravni fakultet u Splitu, Split, 1976.

36. Vrban, D., Država i pravo, Golden marketing, Zagreb, 2003. 


\section{THE CONCEPT OF LAW AND EFFICACY}

\section{Summary}

One of the senses of the term 'efficacy' refers to the fact that norm-addresses actually behave as is required of them by legal norms. This sense of the term is one which is generally used within the jurisprudential discussions about whether efficacy is the essential element of the concept of law. According to legal positivism, efficacy is in some cases and in certain ways the condition of legal validity of both legal norms and legal systems. On the other hand, legal realism tends to entirely identify legal validity or reduce it to efficacy. Thus, in both jurisprudential approaches, efficacy tends to play a role in shaping their respective concepts of law. However, while the legal positivistic view does not affect the most standard sense of legal validity of the legal norm (i.e. the legal norms' membership in the legal system), and does not add much to the explanation of the concept of law by identifying efficacy as the criterion of legal systems' existence, the legal realistic view is faced with some serious objections regarding its explanatory adequacy.

Keywords: $\quad$ Concept of law, legal validity, efficacy, legal norm, legal system 